\title{
THE CARE OF OBSOLETE INSTRUMENTS
}

\author{
Magda Vargha \\ Konkoly Observatory Budapest
}

Hungary is a little country with old traditions. Hungarian celebrate the 950th anniversary of the death of the first king Stephan I this year. As regards astronomy, during the Renaissance in the court of the Hungarian king Matthias I there was a modest flowering in astronomy and this continued until 1526, when because of the Turkish occupation, the region was out off and remained so for centuries. I do not want to list all the tragic historical events. Rather I would like to emphasize what we know by own experiences: what it means to reconstruct destroyed buildings and to try to collect valuable old items that are thrown away by guilty negligence.

Returning to the recent time, according to my experiences that also in peaceful circumstances valuable old things such as books and scientific instruments are in permanent danger. This is true especially when they are not "up to date"but not old enough for antiquarians. Furthermore, the obsolete instruments meet a worse fate. During my working period in the Konkoly Observatory many instruments considered obsolete have been eliminated while the old books have quiet places on our shelves in the library.

With respect to survival, there are many differences between instruments and books. This is the most important difference among them: while an instrument is made in one or in very few copies, the books are printed in hundreds.

One source of trouble is that it is very easy for someone to modify or disassemble an instrument to the point where it is unrecognizable.

While a good librarian knows that she should preserve almost everything for later centuries there is no person whose job is to preserve obsolete instruments.

Hopefully this situation is dealt with better care in other countries.

I know there are many scientists and scholars who are very interested in the old instruments. Also societies have been established by these persons. I wish only to declare the librarians can help this movement founded by lovers of scientific instruments.

The most effective way is to collect and reference completely the old and new books that deal with old scientific instruments. That is also the task of the libraries of the Technical Scientific Museums I know well. But these institutions are relatively new establishments, and their excellent libraries probably could not get all the books that were published centuries before the Museums were founded.

Until recent times, the old instruments, having no possibility to get into scientific museums, were installed in the observatories. This was a very good situation in many ways. You could find in the same place, 
the instruments, the printed resuits made by the help of these items, old letters and diaries that gave description of these instruments, and any other informative documentation.

The situation has changed completely. It is only a rare exception if an observatory has its own museum. We had a rich astronomical collection of old scientific instruments in the Konkoly Observatory before the second World War. Now the instruments are separated from the documantation regarding them. The astronomical librarians do not want to part with the old documents because they fell the best place for them is in the libraries. I fully agree with this. There is a very new fashion in the world, the dynamics of reorganization is the most dangerous disease for old things. The astronomical libraries have a special "historical atmosphere" while the librarians are guarding the old things with special care. They also know well that what today is a current item, will soon have historical value. Supposedly I am very subjective in this question because of my own experiences.

The nucleus of our library was collected in the seventeenth century. Since this time this collection had found a guard - an astronomer or a librarian who felt responsibilty for it. But where are the instruments of late Hungarian observatories? Only a small part survived through history and were added to the Hungarian Technical Museum.

I could have said many sad stories on the fate of some old instruments in Hungary. I mention only one: twenty years ago, the very first Hungarian telescope was thrown into the garbage.

However I am dealing with historical tasks I am not an expert of old instruments, my librarian-work would have demanded deeper experiences in this business.

During the last twenty-three years I have had to give detailed information on old astronomical instruments many times. It was a difficult situation if the "lost" instrument came to light again in a totally unrecognizable form. I had no serious problem if these instruments could be identified by the help of well-known textbooks i.e. BION ${ }^{\top}$, MARINONI AMBRONN 3 , or REPSOLD ${ }^{4}$. But in the case that this was impossible, I tried to detect important data in popular books, biographies or the observatory's publications. It would be very useful to list all this second-hand information by means of a computer.

While searching for any documents on late instruments, often without success, I came upon an idea: Would'nt it be useful if all astronomical libraries had a special documentation of the late instruments that belonged to their observatory? An item might have only two pages, with a photo and a one-page description. It would be a difficult task to start collecting very old documentation now, but records of instruments now becoming obsolete would be easy to organize.

I do not want to burden the librarians with new tasks. We are overhelmed by manifold new disciplines. With such modern advances as magnetic tapes, optical discs, etc., the library would serve as an efficient center for astronomical research work. 
But an astronomical library is not only the center in an astronomical institution. It should be the heart of it. The place where all important information regarding to the previous life of the observatory should be collected.

1 Bion, N., 1741. Mathematische Werck-Schule oder grindliche Arweisung wie die Mathematische Instrumenten nicht allein schicklich und recht zu gebrauchen, sondern auch die beste accurateste Manier zu verfertigen, zu probiren und allezeit in guten Stand zu erhalten, Peter Conrad Monath, Niirnberg.

2 Marinoni, J. J.,1714. De astronomica specula domestica et organico apparatu astronomico libri duo, Leopoldus Joannes Kaliwoda, Vienna.

3 Ambronn, L.,1899. Handbuch der Astronomischen Instrumentenkunde, Bd 1,2, Springer, Berlin.

4 Repsold, J. A., 1908, 1914. Zur Geschichte der astronomischen Messwerkzeuge, Bd 1-2. 1908, 1914, EngeImann, Reinecke, Leipzig. 